\title{
AN INTEGRATED APPROACH TO TEACHING/ STUDYING POSTCOLONIAL POETRY
}

\author{
N. Belgin Elbir ${ }^{2}$
}

\begin{abstract}
This article presents a discussion on teaching/studying postcolonial poetry in English as part of a course on modern and contemporary poetry in a foreign language literature classroom at university level. The argument in the article is based on ways and benefits of using an integrated approach that pays attention to, and puts emphasis on, fostering students' literary and language competence to meet their academic and occupational needs. The particular poems chosen to illustrate the argument are by Grace Nichols and John Agard, two contemporary immigrant poets from the Caribbean, whose work can be regarded as highly representative of the characteristic features and major concerns of much postcolonial poetry produced in Britain by poets from former colonies.
\end{abstract}

Keywords: Foreign language literature, an integrated approach, postcolonial poetry, Grace Nichols, John Agard

\section{Introduction}

The aim of this article is to discuss ways of teaching and studying postcolonial poetry in a course that Turkish students take as part of their undergraduate studies in the Department of English Language and Literature at At1lim University. The course in question is Twentieth-Century and Contemporary Poetry, and is one of the compulsory courses that fourth-year students take. The aim of the course is to make students acquainted with the major trends, movements and developments in modern British poetry, and to improve their ability to read and appreciate poetry. Modern poetry is characterized by diversity and plurality of voices, and poetry by immigrant poets from former colonies of Britain have become an important part of the literary landscape. This is, as R. P. Draper (1999) puts it, "the poetry of English-speaking - or perhaps one should say 'Anglophone' - writers who are embraced (sometimes reluctantly) within the UK, and of former members of the British Empire" (p. 9), and has become a significant field of study in twentieth-century poetry in English. It is within this particular framework that postcolonial poetry is studied in the course. Since the students are studying toward a degree in both English language and literature, the main objective of our program is to help them acquire both linguistic and literary competence that is essential in meeting their scholarly, academic and

2. Professor, PhD at Atılım University, Department of English Language and Literature, Ankara, Turkey, e-mail: belgin.elbir@atilim.edu.tr 
professional needs. Their professional needs following graduation will involve skills that they can only develop through their competence in the English language and literature. Most of them become teachers of English in schools and universities, some continue their academic studies and obtain positions as academics in English language and literature departments at universities, others work in the private and public sector, in jobs where they need to use advanced language skills. The program is, therefore, designed to foster a high level of language and literary competence that will enable students to understand how language creates meaning, to appreciate literature and its cultural significance, and to express their understanding and appreciation of literary, and also nonliterary texts. As language skills are an inseparable part of literary competence, an approach that integrates them in the classroom is best suited to our goals.

A relevant and useful distinction, at this point, in relation to our poetry course is that we are focusing on these texts as literature, not as examples of language use. This is a distinction that refers to the way we describe and distinguish between the aims and content of 'language' courses and 'literature' courses, a distinction between the study of literature and the use of literary texts as resource for foreign language teaching/learning. As Gillian Lazar (1993) points out, the study of literature makes literary texts themselves the content or subject of the course, while the use of literature draws on literature as one source among many other kinds of texts for presenting useful language activities (pp. 13-14). However, language is an integral part of our literature classroom, and one of our main objectives is to have our students understand that it is through language that literary texts create their functional effects and construct their social and cultural meanings. As Ronald Carter and Paul Simpson (1989), who advocate using an approach that integrates literary and language study, state, "language is the literary medium, the more that students are able to understand and describe effects produced by language, the stronger the position they will be in when attempting to account systematically for their intuitions, and to build a base for a fuller interpretation of the text" (p. 18). Carter and Simpson (1989) also emphasize the benefits of using an integrated approach that pays attention to the "existence of an extra-textual world of social, political, psychological, or historical forces" (p. 17), in other words, the contextual properties of texts that affect the way they are interpreted, as well as the "ways in which texts create contexts" (p. 14). This is an approach that regards literature as social discourse, and as literary discourse analysis, seeks to "demonstrate the determining positions available within texts, and show how 'meanings' and 'interpretations of meanings' are always and inevitably discursively produced" (Carter and Simpson, 1989, p. 17).

In postcolonial poetry, where language itself, and the way it is used is made part of the theme and content as being a topic of contention and a means of stressing difference and identity, and functioning as a basis for responding to a particular 
context and forming a social and personal challenge to the conditions of this context, such an integrated approach becomes crucial. In fact, what Carter and Simpson (1989) state about the function of language is highly relevant to the way postcolonial poets use language: "The language we use does not reflect; it refracts a world which we are in but which we can contest and change" (p. 17). Hence in this paper I argue that postcolonial poems present possibilities for integrated language and literature work that will contribute to increasing our students' critical and analytical capacities and prove to be of pedagogical benefit. The particular poems chosen to illustrate the argument are by John Agard and Grace Nichols, two immigrant poets from the Caribbean, whose work can be regarded as highly representative of the characteristic features and major concerns of much postcolonial poetry. The poems are Agard's (2006) "Listen Mr Oxford don" and Nichols's (2012) "Wherever I Hang".

\section{Discussion}

In terms of classroom practice, our goals are best served and the kind of integrated approach described above works to the utmost advantage if it is designed to suit the students' skills and knowledge, and to meet their needs within the objectives of the course. In fact, as Ronald Carter (2007) stated in a relatively recent review of literature and language teaching, the field of literature study and teaching and its place in language education in both theory and practice has developed toward the view that "there is no single 'correct' way of analysing and interpreting the text, nor any single correct approach" (p. 10). The appropriate method is "very much a hands-on approach taking each text on its own merits, using what the reader knows, what the reader is aiming for in his or her learning context, and employing all of the available tools, both in terms of language knowledge and methodological approaches" (Carter, 2007, p. 10). This is a methodology which will hopefully encourage students, as Carter (2007) puts it, "to be active participants in and explorers of linguistic and cultural processes both with an awareness of and an interest in the process itself" (p. 10). In line with Carter's (2007) observations, my guiding principle in this particular course is to take the poems to be studied in class on their "merits", that is, to draw students' attention to the properties and characteristic aspects of the poems that have a role in creating meaning, especially those that the poet has foregrounded; in other words, items, or, "determining positions", by which the poet seems to have made a deliberate choice to create certain effects. To help students to become "active participants" and attentive readers, it is important to make sure that they are engaged with the poems directly, and one effective way of doing this is, doubtless, through class discussion. Discussion is a way of developing and expressing ideas about literature and its effects, it is also a very useful and active way of developing language skills. By the time our students take this fourth-year course, they are fairly confident of their linguistic and literary skills; however, 
since they are non-native students of literature, I strongly believe that, in order to generate discussion, it is necessary to provide questions to draw attention to important aspects of the texts, so as to prevent them from making, what Christopher Brumfit (1986) described as "an inappropriate response through a misunderstanding of the codes being operated" (p. 185). One important point about these questions is the need to structure them in such a way so as to get students to support their ideas, arguments and comments with specific textual references to the poems themselves instead of general information and summaries of poems that they can readily access nowadays.

In order to examine the poems chosen to illustrate some of the main features of postcolonial poetry by immigrant poets, our students need information about the history of colonization and socio-cultural knowledge of the postcolonial Britain where these poets live and produce their work. From a class perspective, it is apparent that this body of information concerning the particular context from which these poets are writing, could be of use in the interpretation of their poems which very often contain references, implicit or explicit, to the historical context as a history and experience of colonization and decolonization, as well as to the social context of the present in terms of both the poets' country of origin and their adopted country, Britain. Therefore, students need to be aware of the various and complex associations created by these references, and to learn about the cultural, socio-historical, political and literary contexts within which these poems are written, published and received. Their knowledge of the historical context will, to a great extent, determine the way they read and respond to the work of postcolonial poets. With postcolonial literature, awareness of this "extra-textual" world is even more significant because for Turkish students who are "outsiders" in that they can identify directly with neither the colonizer British or more widely, the west European, nor the people from former colonies, a knowledge of the postcolonial situation and its pressing issues is essential. This position, on the other hand, could turn out to be an advantage for our students since it can make them more willing to open themselves to what C. L. Innes (2007) argues to be a characteristic quality of postcolonial texts, namely, the "creative and ironic interplay between observer and observed, between insider and outsider" (p. 208).

Such an "openness" necessitates that students become familiar with terms and concepts such as black culture, immigration laws, racial prejudices, political riots and the use of Creole or nation language. One useful essay that students can be assigned to read before starting to study the poems is, Kamau (Edward) Brathwaite's "Nation Language", where Brathwaite (2012) presents a succinct account of the relationship between the history and practice of colonization and language, and discusses the validity and function of using nation language, a term he uses to refer specifically to the West Indian creole English "influenced 
very strongly by the African model, the African aspect of [the] New World/ Caribbean heritage" (p. 2732). Students also need to be informed about the mass postcolonial migrations to Britain after the Second World War. As Jahan Ramazani (2007) writes, poetry has been one of the means by which immigrants have told their history since 21 June, 1948, when the arrival of 492 West Indians at Tilbury Docks, near London, began large-scale immigration by peoples of African, and later Asian descent into Britain. By 1970, nearly half a million West Indians had come to Britain (p. 201). By the 1970s and 1980s, after British politicians had, in the words of Ramazani (2007), "fomented white racism" (p. 208), and after black Britons had been inspired by decolonisation and the civil rights movement, poets of African descent in England started to reimagine the colonial metropolis more assertively (Ramazani, 2007, p. 208). John Agard (2006) and Grace Nichols (2012) are doing this act of reimagining assertively in their poems. They are two of the "diasporic and black British poets with African-Caribbean and African backgrounds, who have played a crucial role in the early and sustained blackening of British poetry" (Ramazani, 2007, p. 201), black British poets whose poems gave voice to the Caribbean people within the English literary tradition. As Innes (2007) remarks, "for many of these poets who came to Britain, there was also a sense of adventure and glamour in the possibility of living in England, and becoming acquainted with the scenes and the culture which had formed the substance of their education" (p. 178). Thus, it can be said that this English literary tradition is part of a "shared culture" (Innes, 2007, p. 178) between the colonizer and the colonized, and as such, a tradition with which the immigrant poet from the Caribbean is also familiar. However, at the same time, the immigrant poets' relation to the British culture is a complex one, fraught with social, political and personal issues such as citizenship, nationality, race, racial prejudice and racial discrimination, all of which are closely bound up with the notion and sense of identity. In much postcolonial poetry, especially that of immigrant poets, identity is a central issue and concern and these poems very often portray characters who express this concern. In other words, "Anglophone" poetry can be defined as "the re-shaping of poetry to express a new conception of identity, or with the purpose of trying to create that identity" (Draper, 1999, p. 9). This "created" identity is not only personal; it acquires symbolic significance in its capacity to represent the community of black immigrants as well. According to Innes (2007), immigrant poets from the Caribbean, like Agard and Nichols, created and reinforced a sense of communal identity and their work "both celebrated and authenticated the presence of Caribbean-inflected voices, and hence, bodies, in Britain" (Innes, 2007, p. 184). "Listen Mr Oxford don" and "Wherever I Hang" have London as their setting; yet they are also, as Ramazani (2007) points out, "'translocal', in that they see the metropolis afresh through the lenses of non-metropolitan history, language and power, and shuttle across and unsettle imperial hierarchies" (p. 202). 
Ramazani's (2007) description of the work of immigrant poets as a "poetry of geographic and cultural displacement" (p. 200) is valid for both poems.

As a first step to class work, it is of great importance to identify the "determining positions" available within the poems, that can form a starting point for productive class work and discussion. In the selected poems, it is mainly by means of the speakers' construction of their self-image and position that the overall effects are achieved. Both poems feature a single, first-person speaker. Both poems progress discursively, and move toward a state of self-affirmation. In other words, both poems construct a poetic persona, or, a self, whose words reveal a dramatization of what he or she is experiencing in a particular place and at a particular historical moment. Therefore, it is important for students to pay attention to these characters and the way they are presented. This will involve examining the linguistic processes employed in their construction. In the two poems chosen to be studied in class, since the first-person speakers determine the conditions and terms of the poems' discourse, it is of great importance to examine them. In both poems, the speakers are deliberately made visible by what they say and how, which indicates that any interpretation of the poems needs to take into consideration their active presence. In other words, the foregrounding of this particular feature is deliberate, and as such, a central element in the creation of the effects and meaning(s) produced by the poems. Linguistic variation between standard and non-standard forms of English in the speakers' discourse is a common characteristic of these poems, and students would probably notice it at their first reading. They need to respond to this variation in style for it is an important element in the construction and dramatization of the speaker's identity. In both poems, linguistic variation usually occurs in the form of deviation from expected usage, and the use of Creole English together with standard English creates a text that linguistically corresponds to the indeterminacy that characterises the position of the postcolonial subject. In studying postcolonial poetry, these linguistic deviations can, I believe, provide the teacher with a starting point in motivating students to examine the text closely. One way of initiating this activity is to ask them to reflect on the effects produced by the poets' suspension and disruption of certain rules of grammar. Both Agard and Nichols make use of Creole words and syntactical patterns to construct what can be described as a linguistic resistance and challenge that is, at the same time, politically significant. They are skilful poets and they break the rules deliberately and consciously for "the attack on the empire's literary, grammatical and orthographic norms is central to black British poetry's effort to reconfigure the politics of race in 1970s and 1980s Britain" (Ramazani, 2007, p. 208). I would like to add here that while studying postcolonial poems in the classroom, especially poems like Agard's and Nichols's that engage with notions of language, reading aloud and listening to recorded readings of the poems can help students to come to a realization of the oral properties of the 
poems, and the use and function of Creole in creating the speaking voice. In terms of class work, this realization could lead to a consideration of how the poets' use of Creole along with standard English creates possibilities for rhythm and rhyme that can have a great impact on the way readers "hear" the speaking voice. Since Agard's (2006) "Listen Mr Oxford don" was first published in 1985, earlier than Nichols's poem which was published in 1989, it is a good idea to start by examining it before moving on to "Wherever I Hang".

Following are suggestions for points to be emphasized in order to elicit comments and to develop a productive discussion on the poems in the classroom:

"Listen Mr Oxford don" is designed to present an imagined situation in which an immigrant speaker encounters and addresses an Oxford don. The class discussion can initially focus on what assumptions it is possible to make about the speaker and the don within this imagined encounter. The speaker is the 'me' and 'I' of the poem. The addressee of the title, "Mr Oxford don" is a source of authority over linguistic and cultural conventions. The speaker is, as his descriptions of his activity reveal, a poet; "the Oxford don" and "dem" in the poem represent the ruling class, the administrators; and the poem shows that there is a struggle between the "I", and the "Oxford don" and "dem". The analysis of the patterns of interaction between the speaker and the silent "Oxford don" is of crucial importance in the interpretation of the poem for it is within this interaction that the speaker's identity, position and attitude are formed. At the beginning of the poem the speaker positions himself as different and inferior to the don:

Me not no Oxford don

me a simple immigrant

from Clapham Common

I didn't graduate

I immigrate (Agard, 2006, p. 2542)

Yet this positioning is changed immediately in the second verse where a context of conflict is introduced:

But listen Mr Oxford don

I'm a man on the run

and a man on the run

is a dangerous one (Agard, 2006, p. 2542)

The don's power is challenged by the use of "But" and the imperative form "listen", and also by the speaker's declaration of himself as "dangerous". The third and fourth verses begin to clarify the terms of the speaker's challenge:

I ent have no gun

I ent have no knife 
but mugging the Queen's English

is the story of my life (Agard, 2006, p. 2542)

The speaker's challenge is rendered more effective through the intensity and urgency of the speaking voice. The identity of the speaker and the force of his speaking voice provide excellent opportunities for classwork. How is the speaker's identity constructed and revealed? What stylistic choices are involved in the dramatization of the terms of his challenge to the don? Questions such as these can be expected to motivate students to engage with the poem closely. They can be asked to point out the instances of non-standard English in the poem, and to comment on the function of these deviations from the norm. Their attention can be drawn to rhetorical devices such as the frequent use of the enjambment, the use of imperatives, the elliptical phrases and repetitions. Another striking feature of the poem, which students are likely to notice, is the absence of punctuation. Once students have become aware of this, they can be asked to concentrate on it in terms of its contribution to the effect of representing "spoken" language.

The immigrant is someone, as the poem shows, who breaks rules of English grammar and syntax. He portrays himself as a criminal but his crime is not physical violence since he does not have a "gun" or a "knife". He reveals himself to be a "mugger", somebody who attacks with the intention of robbery; however, it is the linguistic norms that he attacks. What enables him to perform this act of "mugging" is ironically indicated by the Oxford dictionary on which, he says in the sixth stanza, "Dem accuse me of assault" (Agard, 2006, p. 2542). Another meaning of the verb "to mug" apart from "to attack" is given in the Oxford Dictionary as to "become familiar with sth on which one is to be tested" (Hornby, 1974, p. 564). In other words, it is the immigrant speaker's study and familiarity with the standard English that makes him a "mugger". In the entire poem, words such as "gun", "knife", "assault", "riot", "dangerous" and "mugging" are used to suggest the prejudiced notion of the black man as a criminal, and at the same time to subvert this notion by demonstrating that his criminality consists of disrupting the accepted linguistic patterns of the Queen's English to construct a poetic discourse that asserts his identity as a black poet. The lines "to split/up yu syntax", "to mash/ up yu grammar" (Agard, 2006, p. 2542), and "I slashing suffix in self-defence" (Agard, 2006, p. 2543) in the poem can be taken as evidence of his mastery of the English syntax, grammar and suffixes.

For the students, specific background information is necessary to understand the nature of Agard's protest and skill as a poet. As Fred d'Aguiar (1993), himself a postcolonial writer and poet, writes, the year 1981 saw the first of the big riots, centred around the black communities, that would characterise the early to mid-eighties. In January 1981 the New Cross Massacre took place, 
and thirteen black youths died by fire under suspicious circumstances. March saw the biggest demonstration held by black people in Britain. A generation of British-born blacks who had come of age realized with dismay that Britishness did not include them. They could not find jobs and were discriminated against at school. There was also an increase in racist violence. This bleak situation led artists and poets to find ways of expressing their protest through their art. Therefore, in D'Aguiar's (1993) opinion, the riots by black people cannot be viewed simply as destructiveness by mindless young people but need to be seen as a form of protest (D'Aguiar, 1993, p. 58-59). Agard's reference to these riots in his "dem want me serve time / for inciting rhyme to riot" (2006, p. 2542) acquires importance as a metaphor that subverts the meaning and implications of the word "riot" within this particular context of a crisis in British politics of race. As Draper (1999) comments, "the question of victimisation is of importance to the Anglophone West Indian writer" (p. 204), "for the black poet (male or female) racial prejudice is an inescapable context" (p. 213). Agard's speaker is apparently someone facing racial prejudice; someone regarded as an outsider and a criminal. It should be noted here that the speaker is actually creating end rhymes as the above lines are followed by "but I tekking it quiet / down here in Clapham Common" (Agard, 2006, p. 2542), for the words "riot" and "quiet" are end rhymes. Thus, rhyme is made to "riot", yet it is only by the act of "inciting riot" that rhyme, a frequent feature of the art of poetry, is achieved. This example will enable students to agree with D'Aguiar's comment that "perhaps the don would give him full marks for his use of metaphor" (1993, p. 62), a comment stressing the speaker's skill as a poet in using figurative language to convey meaning.

The ' $\mathrm{I}$ ' is challenging and defying the don in an aggressive manner, but also complaining to him and forcing him to pay attention to the unjust accusations by the authorities who are represented in the poem by "dem". In that sense, it can be said that the speaker's address is an appeal, as well as a defiance; an appeal to be heard and understood as a human being, that forms a part of the challenge presented by the immigrant speaker to the powerful Oxford don. Kamau Brathwaite's (2012) description of "nation language" as being "an English which is like a howl, or a shout" (2733) points to the function of using Creole in representing the cry of a person in pain. It is a long and painful cry of resentment and defiance, also a cry of pain that Agard, through his poet-speaker's voice, is able to articulate in the form of a poem forcing all his readers as well as the Oxford don to pay attention. To do that he is presenting the Oxford don's English as the official language of the ruler, the colonizer, of the written and formal culture, against which he places the informal language of the colonized people, the language of a culture that belongs, to a great extent, within an oral tradition that depends for its effects on the power of the "human breath" as the speaker states with confidence towards the end of the poem: 
I'm not a violent man Mr Oxford don

I only armed wit mih human breath

but human breath

is a dangerous weapon (Agard, 2006, p. 2543)

The expression "human breath" refers to the power of the spoken word to effect political and cultural change by challenging the hegemony of the present authority, and serves to imply that he is going to continue to speak up. It would be useful here to examine how the speaker refers to the future, particularly when he explicitly declares at the very end, "I bashin future wit present tense / and if necessary / I making the Queen's English accessory/to my offence" (Agard, 2006, p. 2543). At this stage, referring students to Brathwaite's statement in "Nation Language" that it is, after all, "not language, but people, who make revolutions" $(2012$, p. 2733) could very well lead to a debate on the question of human agency and the role of language as an agent in bringing about change.

To wrap up the discussion, it is worth emphasizing that by means of his skill to fashion a poem, making use of a number of poetic devices such as stanzas, lines, rhythm and rhyme, while at the same time disrupting the rules of standard English through his use of Creole, the speaker is showing that Creole is suitable for poetry and can be employed creatively to produce poetry that expresses urgent issues of public and personal significance in British culture. He is asserting his presence and his being culturally at home, because it is a shared literary tradition that he is drawing upon. His ability to devise an attack on language depends on his knowledge of the linguistic order of that language, which is a sign of his complex relation to British culture and the Queen's English, and the reason for his demand to be recognized as a human being in this culture.

"Wherever I Hang" differs from "Listen Mr Oxford don" in the absence of an identifiable addressee whom the speaker imagines to be encountering. Another difference lies in the nature of the conflict dramatized by the speaker. Nichols's (2012) poem is in the form of a soliloquy, portraying a speaker who, through her presence, voice and memory, is able to present and explore her personal thoughts and feelings on various aspects of her experiences as an immigrant postcolonial subject in postcolonial Britain, specifically in London. The conflict is mainly within herself. It is an internal debate, rather than an address that poses an explicit challenge to authority as in Agard's (2006). Memory becomes part of the identity of Nichols's speaker as her past and present interact. Memories of the past and awareness of the present signified by the changing scenes from the Caribbean, her former home, and England, her new country, come to stand for the speaker's sense of being torn between her old and new selves. This feeling of in-betweenness is an important element in the poem, that can be developed in class towards a sound interpretation. Specific questions would assist students in their analysis: How does the poem suggest a feeling of in-betweenness? What 
are some of the signs of Britishness in the poem? How does the style of the poem contribute to the way this feeling is created? Why and how does the speaker refer to English social customs and habits? In what way are these customs and habits different from the speaker's former ways? How can we describe her reaction to these signs of Britishness? Does she feel nostalgic, lost, alienated, or confused? Could she be experiencing all of these feelings? Can she find a solution to her dilemma?

At the beginning of the poem the speaker recalls how she left her home and came to live in England:

I leave me people, me land, me home

For reasons, I not too sure

I forsake de sun

And de humming-bird splendour

Had big rats in de floorboard

So I pick up me new-world-self

And come, to this place call England (Nichols, 2012, p. 2752)

Students would certainly notice in the above-cited lines the deviations from linguistic norms such as "me", "I not too sure", "de" and "this place call England". They would be prepared to discuss the implications of this feature of style in the way the speaker's identity is constructed. Her reference to "me new-worldself" designates a "me old-world-self". The style attests to the fact that the old self is part of the speaker's identity. It can be useful at this point to ask students to read Nichols's "Epilogue", a very short poem that she placed at the end of her collection The Fat Black Woman's Poems published in 1984. "Epilogue" expresses the black woman's new identity in terms of her new language: "I have crossed an ocean / I have lost my tongue", yet "from the root of the old one / a new one has sprung" (2012, p. 2751).

In "Wherever I Hang", as the speaker's memories of her former home are juxtaposed with images of her present place of living, where she cannot feel truly at home, her sense of self and being in-between, continue to be indicated by the shifts of language between Creole and standard English, the language of the colonizer, which she shows herself to be perfectly capable of using. As in the poem by Agard (2006), Nichols's (2012) switches between Creole and standard English manifest the presence of a tension, experienced by the speaker, between the Caribbean and the British, in other words, between her old-world and newworld selves. She is very much aware of a physical environment which is greatly different to her native country. She is also aware of her history as a member of a colonized country. The lines "And when I look up to de sky / I see Lord Nelson high - too high to lie" (Nichols, 2012, p.2752) place the statue of the British Admiral Nelson who spent time in the Caribbean, as a representative figure of British imperial and colonial power, to evoke the history of colonization. As the 
poem progresses, the speaker shows herself as adopting the ways of her new country:

And is so, little by little

I begin to change my calypso ways

Never visiting nobody

Before giving them clear warning

And waiting me turn in queue (Nichols, 2012, p. 2754)

She says she gives up her calypso ways, gets used to behaving the way the English people do. When considered from the perspective of the connotations of the word calypso, that is to say, its reference to Caribbean traditions and to "calypso's carnivalesque inversion of power structures" (Ramazani, 2007, p. 205), this statement can imply an acceptance on the part of the speaker. Yet it is a stoic acceptance, complicated by the speaker's declarations towards the end of the poem:

But I still miss back-home side

To tell you de truth

I don't know really where I belaang

Yes, divided to de ocean

Divided to de bone

Wherever I hang me knickers - that's my home (Nichols, 2012, p. 2754)

The double spaces that position the lines "Yes, divided to de ocean / Divided to de bone" as separate from the ones coming before and after draw attention to themselves as stylistic devices that enact pauses in the speaker's reflections. The word "yes" confirms, within her inner debate, her sense of divided and conflicting loyalties after she has "confessed" that she is still missing her home in the Caribbean. Her final declaration at the end of the poem, after another pause, becomes a means of coping with the challenges and difficulties of her "new- world-self" in the new world; it can be regarded as a means of survival, if not here somewhere else, wherever she hangs her knickers. Students should be alerted to the significance of the clause "wherever I hang my knickers" as providing a particular condition which is a prerequisite, something indispensable, if the speaker is going to make England her home. It is important to get them to see the function of "wherever", an adverb that refers to any place, not to a specific one. When the speaker's immigrant status is considered, this adverb acquires further significance as hinting at the possibility of moving or immigrating to another place, which is a sign of instability and uncertainty. The final declarative sentence "that's my home" thus affirms the speaker's determination to find a home, a centre of permanence, within the instability that "wherever" emphasizes. The speaker's use of the demonstrative pronoun "that" is an element of style that renders the declaration so emphatic. The statement 
"Wherever I hang my knickers - that's my home" is, at the same time, unexpected and ironic. The act of hanging her knickers is a trivial one connected with domestic chores, and hence contrasts with the image of the speaker as someone preoccupied with reflections upon important issues such as identity and divided loyalties. From this perspective, the act of doing her laundry provides a sense of humour that can be regarded as a strategy for, in the words of Ramazani (2007), "creolising the heart of the empire" (p. 209). Humour can prevent the speaker from becoming overwhelmed by her reflections. Another equally valid way of looking at the effect produced by this particular act could be to see it as part of the challenge the speaker presents as a black female immigrant. The item she hangs is a very personal and intimate piece of clothing which gains symbolic significance in relation to the female body and its freedom to assert itself. She is making a declaration, declaring her determination to make a home for herself. The fact that she makes this declaration by switching to standard English, specifically from "me" to "my", can be regarded as an association of this "home" with not "anywhere" but England, at least for as long as she can "hang [her] knickers". At the end of the poem, by switching to "my", the speaker adopts the linguistic formula that is suitable for her "new-world-self"; in other words, the self that has come to live in England. Nichols is here making use of the conventional notions of the word home as a place that provides security, protection and privacy, and subverting the notion of home in the very English and well-known saying "an Englishman's home is his castle" to refer to the Caribbean immigrant woman's home where she can hang her underwear. This last image thus serves to emphasize the difference between the playful Caribbean woman and the reserved and disciplined English people, or, more specifically, the English men. The issue of race and nationality intersects with the issue of gender, adding another dimension to the speaker's reflections on her identity and position. Students might be encouraged to discuss how and why the speaker expresses her engagement with this issue of gender in her argument. The last line of the poem, "Wherever I hang me knickers - that's my home" is, in fact, two lines brought together by means of indentation, to enact and to reinforce the mental process of thinking and coming to the final decision that she will have her home wherever she can assert her identity, in spite of the sense of dividedness she feels and has already recorded. The poem ends as a personal and moving account of a person's efforts to make for herself a new home in a new country to which she feels related in a number of complicated and troubling ways.

\section{Conclusion}

At the end of our study of the selected poems, within the overall aims of the course, it is expected that students will have an informed idea of how poems can become sites of social and cultural transformation, of anxieties and tensions, 
where matters of deep significance and urgency can be articulated and explored. They will have an understanding of postcolonial poetry as offering, in the words of Draper (1999), "sharply particularized, idiosyncratic styles which, though they may create difficulties (linguistic and otherwise) for outside readers, have unique energy and expressiveness" (p. 163). They will be able to appreciate that poetry has been a powerful resource through which immigrant black poets, as literary artists and non-English speakers of English, have expressed their identity and their place in modern British culture in ways that have contributed greatly to the richness of modern poetry in English. Furthermore, students' appreciation of these poems will, hopefully, help them in their reading and study of other poems by postcolonial poets, and motivate them to further reading and study.

\section{References:}

Agard, J. (2006). Listen Mr Oxford don. In S. Greenblatt, C. Christ, A. David, B. Lewalski, L. Lipking, G. Logan, D. Lynch, K. Maus, J. Noggle, J. Ramazani, C. Robson, J. Simpson, J. Stallworthy \& J. Stillinger (Eds.), The Norton Anthology of English Literature: Vol. 2. (8th ed., pp. 2542-2543). New York, NY: W. W. Norton \& Company, Inc.

Brathwaite, K. (2012). Nation language. In S. Greenblatt, C. Christ, A. David, B. Lewalski, L. Lipking, G. Logan, D. Lynch, K. Maus, J. Noggle, J. Ramazani, C. Robson, J. Simpson, J. Stallworthy, J. Stillinger (Eds.), The Norton Anthology of English Literature: Vol. 2. (9th ed., pp. 2729-2733). New York, NY: W. W. Norton \& Company, Inc.

Brumfit, C. (1986). Reading skills and the study of literature in a foreign language. In C. Brumfit \& R. Carter (Eds.), Literature and Language Teaching (pp. 184-190). Oxford: Oxford University Press.

Carter, R. (2007). Literature and language teaching 1986-2006: A review. International Journal of Applied Linguistics, 17(1), 3-13. Doi: 10.1111/j.1473-4192.2007.00130.x

Carter, R., \& Simpson, P. (1989). Introduction. In R. Carter \& P. Simpson (Eds.), Language, Discourse and Literature (pp. 1-20). London: Unwin Hyman.

D’Aguiar, F. (1993). Have you been here long? Black poetry in Britain. In R. Hampson \& P. Barry (Eds.), New British poetries: The scope of the possible (pp. 51-71). Manchester and New York, NY: Manchester University Press.

Draper, R. P. (1999). An introduction to twentieth-century poetry in English. Houndmills, Basingstoke, Hampshire, London: Macmillan Press.

Hornby, A. S. (1974). Oxford Advanced Learner's Dictionary of Current English. London: Oxford University Press.

Innes, C. L. (2007). The Cambridge Introduction to Postcolonial Literatures in English. Cambridge: Cambridge University Press.

Lazar, G. (1993). Literature and language teaching. Cambridge: Cambridge University Press.

Nichols, G. (2012). Epilogue. In S. Greenblatt, C. Christ, A. David, B. Lewalski, L. Lipking, G. Logan, D. Lynch, K. Maus, J. Noggle, J. Ramazani, C. Robson, J. Simpson, J. Stallworthy \& J. Stillinger (Eds.), The Norton Anthology of English Literature: Vol. 2. (9th ed., p. 2751). New York, NY: W. W. Norton \& Company, Inc. 
Nichols, G. (2012). Wherever I Hang. In S. Greenblatt, C. Christ, A. David, B. Lewalski, L. Lipking, G. Logan, D. Lynch, K. Maus, J. Noggle, J. Ramazani, C. Robson, J. Simpson, J. Stallworthy \& J. Stillinger (Eds.), The Norton Anthology of English Literature: Vol. 2. (9th ed., pp. 2752-2754). New York, NY: W. W. Norton \& Company, Inc.

Ramazani, J. (2007). Black British poetry and the translocal. In N. Corcoran (Ed.), The Cambridge Companion to Twentieth-Century English Poetry (pp. 200-214). Cambridge: Cambridge University Press. 